\title{
Estimation of Several Commercial, Phenotypic and Reproductive Traits' Performance Using the Quantitative Genetic Method for Kamper Chicken Line
}

\author{
I Wayan Swarautama Mahardhika, Abiyyayumna Rif'at Chasnaurosyiqoh, Joseph Chohansandhika, \\ Feren Putri Sholiha, Nurachmad Bagas Indriarto, Budi Setiadi Daryono* \\ Gama Ayam Research Team, Laboratory of Genetics and Breeding, Faculty of Biology, Universitas Gadjah Mada \\ Jl. Teknika Selatan, Sekip Utara, Sleman, Yogyakarta, Indonesia. 55281 \\ *Email: bs_daryono@mail.ugm.ac.id
}

\begin{abstract}
In this study the genetic resource of Pelung chicken from Cianjur, West Java, Indonesia, was exploited. Pelung chicken has a higher body weight growth, unique meat flavor, and superior posture, compared with other indigenous breeds. Kamper chicken line selective breeding program was conducted, to increase the performance of Pelung breed by crossing with Layer Lohmann Brown-Classic. The Layer Lohmann Brown-Classic is an imported laying-type breed, which is widely known for its reproductive performance, based on the egg productivity. This study aims to use quantitative genetic method in estimating the commercial and reproductive traits' performance of Kamper chicken line. Based on commercial, phenotypic and reproductive traits, the progenies in Kamper chicken line have significant improvements, compared to the parental cross of Pelung and Layer Lohmann Brown-Classic. The quantitative genetic method was used in describing and underlying some phenomenon, in the selective breeding program. The results showed that the phenotypic and reproductive types of progenies in Kamper chicken, have significant improvements compared to the parental crossing of Pelung breed and Layer Lohmann Brown-Classic. Although quantitative genetic method is utilized in basic breeding program with significant precision and rapidness, it is only used in the preliminary study, for the advanced type. Therefore, the addition of quantitative trait loci (QTL), provide a more thorough genetic examination, and play a role in selective breeding program.
\end{abstract}

Keywords: genetic; indigenous chicken; Kamper chicken line; QTL; quantitative method

\begin{abstract}
Article History: Received 1 September 2020; Received in revised form 23 October 2020; Accepted 9 November 2020; Available online 30 December 2020

How to Cite This Article: Mahardhika IWS, Chasnaurosyiqoh AR, Chohansandhika J, Sholiha FP, Indriarto NB, Daryono BS. 2020. Estimation of several commercial, phenotypic and reproductive traits' performance using the quantitative genetic method for Kamper chicken line. Biogenesis: Jurnal Ilmiah Biologi. vol 8(2): 172-184. doi: https://doi.org/10.24252/bio.v8i2.15648.
\end{abstract}

\section{INTRODUCTION}

Human population growth subsequently aligns with the increasing demand for food production. The rise in the world population and urbanization increase the demand for poultry meat and eggs, which is expected to grow at a rate of $20 \%$ in the next decade (Diambra-Odi, 2014; Mottet \& Tempio, 2017). To close the gap in the food sector, there is a need to empower innovation, collaboration, and research, in providing the necessary solution. Innovative method for empowering local biodiversity, do not only provide the required food, it also act as a conservative effort, and a step closer to local food independence. Indonesia has one of the largest biodiversity resources in the world, however, facing the same challenge in the food sector. Agriculture and poultry sectors have long been the backbone of Indonesia's food main source, although they are currently dependent on foreign products, such as feed, seeds, and various commercially domesticated animal breeds. While the innovation and research of natural feeding source continues to improve, in order to replace food additive, for example using herbs or in combination with probiotics, Lactobacillus spp. (Risdianto et al., 2019). Therefore, an approach to genetic improvement is needed, in providing a more sustainable solution.

The indigenous species are valuable resources for livestock development, because their extensive genetic diversity allows the rearing of poultry, under varied environmental conditions, providing a range of products and functions (Nwenya et al., 2017). In classification, Indonesia's indigenous chicken are identified by the type of meat, laying method, and ornament. Henuk \& Bakti (2018) 
classified Indonesia's indigenous chicken into 34 distinct breeds, Ayunai, Balenggek, Banten, Bangkok, Burgo, Bekisar, Cangehgar, Cemani, Ciparage, Gaok, Jepun, Kampung, Kasintu, Kedu (hitam and putih), Pelung, Lamba, Maleo, Melayu, Merawang, Nagrak, Nunukan, Nusa Penida, Olagan, Rintit atau Walik, Sedayu, Sentul, Siem, Sumatera, Tolaki, Tukung, Wareng, Sabu, and Semau. All are known as Kampung chicken with high nutritional value, and has high demand in the local market. Kampung chicken is mostly bred by villagers in Indonesia, because it is easily maintained, has high nutritional meats, and suitable posture. Also, its eggs are in high demand due to its nutritional content. A trend of exploiting indigenous chicken breed into local poultry sector has been increasing, especially in developing countries for example, a study of native chickens from Mazandara (Niknafs et al., 2013), Nigeria (Nwenya et al., 2017), and Korea (Manjula et al., 2018). Nwenya et al. (2017) stated that, great genetic resources are embedded in the indigenous poultry, awaiting full exploitation that provide basis for genetic improvement and diversification. And also, to produce breeds that are adapted to local conditions for the benefits of farmers, especially in developing countries. The use of major genes in improving productivity of smallholder poultry breeding programs, has been researched in various tropical countries (including Indonesia, Malaysia, Thailand, Bangladesh, Bolivia, India, Sri Langka, Cameroon, and Nigeria) (Katano et al., 2011; Samaraweera et al., 2014).

This study exploited the genetic resource of Pelung chicken from Cianjur, West Java, Indonesia. This breed has a higher body weight growth, unique meat flavor, and superior posture, compared with other indigenous breeds (Mahardhika \& Daryono, 2019). Although, Pelung has diverse characteristics, its high variation in body weight, slow growth performance, and lower reproductive traits are obstacles for the commercialization. Kamper chicken line selective breeding program was conducted to increase the performance of Pelung breed by crossing with Layer Lohmann Brown-Classic. The Layer Lohmann Brown-
Classic is an imported laying-type breed, widely known for its reproductive performance, based on the egg productivity. This study aims to use quantitative genetic method, in estimating commercial and reproductive traits' performance of Kamper chicken line. Quantitative model is a rapid, practical and cost-saving method, which is applied by breeders, especially in poultry industry as a method of increasing effectiveness in breeding program. Therefore, understanding this method help the breeders in Indonesia, to be consistent in characterizing and conserving gene pool.

\section{MATERIALS AND METHODS}

This study was conducted at the Pusat Inovasi Agro Teknologi (PIAT) Universitas Gadjah Mada, Berbah, Daerah Istimewa Yogyakarta, Indonesia. Berbah is situated between latitude $7^{\circ} 47^{\prime} 45.1^{\prime \prime} \mathrm{S}$ and longitude $110^{\circ} 27 ' 55.0^{\prime \prime} \mathrm{E}$, at the elevation of $489 \mathrm{~m}$ above sea level. PIAT UGM facilitated this study since 2014 to 2019, with the assistance of local residents under the supervision of Gama Ayam.

Experimental Animal, Feed and Equipment. The research team were from the Laboratory of Genetics and Breeding, Faculty of Biology, Universitas Gadjah Mada. The broodstock consisted of fifty females from Layer Lohmann Brown-Classic and ten males of Pelung. The ten males of Pelung were acquired from Cianjur, West Java, Indonesia by purchasing them from specialized local breeders. Both of the species were mated in a ratio of 5:1 respectively. After this, progenies were mated in the same ratio, during selective breeding program. The breeding groups in Kamper chicken line were $+\mathrm{L} \times \bigcirc^{\lambda} \mathrm{L}$ (Layer Lohmann Brown-Classic $\times$ Layer Lohmann Brown-Classic), $\stackrel{+}{ } \mathbf{P} \times{ }^{\lambda} \mathrm{P}$ (Pelung $\times$ Pelung), $\uparrow \mathrm{L} \times{ }^{\top} \mathrm{P}$ (Layer Lohmann Brown-Classic $\times$ Pelung),, $\mathrm{GAK} \times{ }^{\hat{}} \mathrm{GAK}$ (Gama Ayam Kamper $\times$ Gama Ayam Kamper), + Lx $\bigcirc^{\uparrow} \mathrm{GAK}$ (Layer Lohmann Brown-Classic $\times$ Gama Ayam

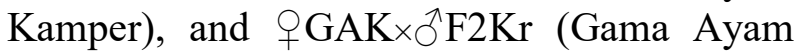
Kamper $\times$ F2 Kamper).

Management of Experimental Birds. Both broodstock and progenies were reared under semi-intensive, with ad-libitum standard feed diet of AD-II and BR-1 (Ummah et al., 
2019). Broodstock of each breeding group were fed with ad-libitum AD-II (15\% Crude Protein), as well as the administration of vaccine and prophylactic medications, to ensure optimal health of the chickens. The Day-Old-Chicks (DOCs) of each breeding group were reared intensively in insulated bamboo pens. The DOCs were fed with ad-libitum BR-1 (22\% Crude Protein, $3050 \mathrm{Kcal} \mathrm{ME} / \mathrm{kg}$ ). The fourweeks-old chickens of each breeding group were transferred into the larger shed $\left(8 \mathrm{~m}^{2}\right)$, under a semi-intensive rearing system feeding on ad-libitum BR-1 diet for eight weeks.

Parameters Measured. The commercial traits measured were body weight (BWT), femur length (FL), tibia length (TL), chicken height $(\mathrm{CHt})$, body height $(\mathrm{BHt})$, wingspan (WS), and chest circumference (CC). The bodyweight growth of DOCs from each breeding group was monitored and measured over eight weeks period. This was followed by observation and measurement of phenotypic traits at the $8^{\text {th }}$ week. The bodyweight growth performance and egg weight were measured with a digital scale KrisChef EK9350H, and obtained 0.01-gram accuracy per week. A total of 20 hens of each breeding group were observed for the reproductive traits, during 16 weeks period. The reproductive traits measured were egg productivity (EP), hen day production (HDP), egg shape (ES), egg heritability $\left(\mathrm{h}^{2}\right)$, eggshell colour (EC), egg weight (EW), and egg nutritional content. The phenotypic traits observed were feather and shank colour. The egg nutritional content was determined with proximates analysis, in Laboratory of Food Technology and Agricultural Products, Universitas Gadjah Mada, Yogyakarta.

Quantitative Genetic Method. The data collected were subjected to analysis of variance (ANOVA), using IBM@ SPSS@ Statistics version 21. The significant means were detected using Duncan's multiple range test. The percentage heterosis was estimated using linear contrast procedure, as described by Nwenya et al. (2017). The egg shape index was estimated to determine the shape, by calculating the ratio between the weight (W) and length (L), and multiplied by 100 (Reddy et al., 1979; Anderson et al., 2004; Duman et al., 2016).
Heritability was estimated, based on egg shape and weight (Alwell et al., 2018). The inbreeding depression (Fx) and rate (F) were estimated as described by Telalbašić et al. (2007), and Sawitri \& Takandjandji (2012). The phenotypic traits were estimated as allele frequency, described by Perdamaian et al. (2017). The detail procedures were as follows:

$$
\begin{aligned}
& \text { Percentage Heterosis } \\
& =\frac{\text { Crossbred average }- \text { Purebed average }}{\text { Purebred average }} \times 100 \\
& \text { Egg Shape Index }=\frac{\text { Egg Width }}{\text { Egg Length }} \times 100 \\
& \mathrm{Fx}=\Sigma(1 / 2)^{\mathrm{n}+n^{\prime}+1}(1+\mathrm{FA}) \\
& \mathrm{F}=1 /(8 \mathrm{Nm})+1 /(8 \mathrm{Nf}) \\
& \text { Allele frequency }=\frac{\text { Traits observed }}{\text { Population size }} \times 100 \%
\end{aligned}
$$

Animal Care. This study was performed in accordance with the Animal Welfare Act of Indonesia, and all the procedures involving the handling of animals were approved, by the local office of occupational and technical safety (Ethical Clearance Commission of Integrated Research and Testing Laboratory, Universitas Gadjah Mada, Yogyakarta No: 00038/04/LPPT/VI/2018).

\section{RESULTS AND DISCUSSION}

Commercial Traits Performance and Phenotypic Traits. The main progenies of crossbreeding between the fifty females Layer Lohmann Brown-Classic and the ten males Pelung, resulted to the main $\left(\mathrm{F}_{1}\right)$, Gama Ayam Kamper, and the crosses between the Kamper of $\mathrm{F}_{2}, \mathrm{BC}_{1}$, and Golden $\mathrm{BC}_{1}$. In Fig. 1, the detail on Kamper chicken line selective breeding program is depicted. For almost a decade, Gama Ayam Research Team has been conducting selective breeding program on Kamper chicken line. The parental generation of Layer Lohmann Brown-Classic and Pelung were crossed several times, to produce main progenies of $F_{1}$ Kamper or Gama Ayam Kamper. The three characters underlying the selection for the next crosses were traits from commercial (i.e., body weight performance, 
FL, TL), phenotype (i.e., shank and feather colour), and reproduction (i.e., EP, ES)

Each crosses were different in purpose, those between female Layer Lohmann BrownClassic and male Gama Ayam Kamper, produced backcross hybrid and $\mathrm{BC}_{1}$ Kamper based on the reproductive traits. The crosses between Gama Ayam Kamper, produced inbred generation of $F_{2}$ or Golden Kamper, in order to increase homozygosity based on commercial and phenotypic traits. The crosses between Gama Ayam and $F_{2}$ Kamper produced backcross hybrid of $\mathrm{BC}_{1}$ Golden based on the traits of commercial, reproduction, and phenotype. Cheng (2010) suggested that, the principle of artificial selection of chickens, is similar to that of natural selection, such as selecting the best animals with the highest survivability and reproducibility. Domesticated animals are spectacular from their original native partners, in terms of behavioral, physical, or physiological characteristics. Artificial selection is the traditional method that cause genetic improvements in farm animals (Stamps \& Groothuis, 2010; Tallentire et al., 2018) i.e., the animals with variations that are better fitted to the production conditions, are chosen to breed, therefore, passing on their favorable characteristics (specific genes) to their offspring (Cheng, 2010).

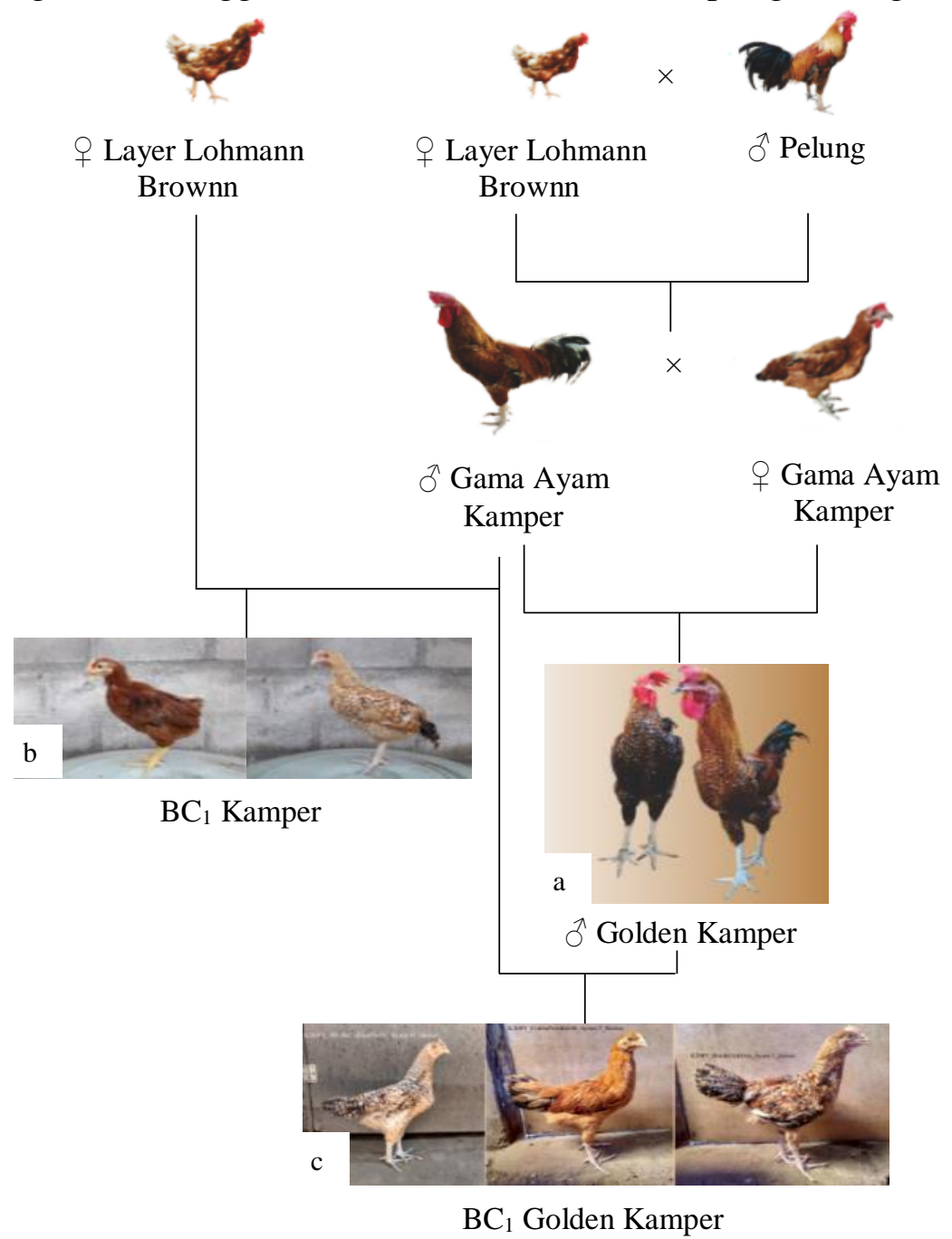

Fig. 1. Diagram of the development scheme for Kamper chicken line selective breeding program. The crosses between the female Layer Lohmann Brown-Classic (L) with the male Pelung (P) were carried out several times, to produce the main progenies, $F_{1}$ or Gama Ayam Kamper (GAK). The crosses between Gama Ayam Kamper produced inbred generation a. The $\mathrm{F}_{2}$ Kamper $\left(\mathrm{F}_{2} \mathrm{Kr}\right)$ or the Golden Ayam were chose by preliminary selection based on feather colour. The crosses between female Layer Lohmann Brown-Classic with male Gama Ayam Kamper, produced backcross hybrid; b. The $\mathrm{BC}_{1}$ Kamper $\left(\mathrm{BC}_{1} \mathrm{Kr}\right)$ were chose based on reproductive traits performance. The crosses between female $\mathrm{F}_{2}$ and male Gama Ayam Kamper produced backcross hybrid; c. The $\mathrm{BC}_{1}$ Golden Kamper $\left(\mathrm{BC}_{1} \mathrm{GKr}\right)$ were chose by preliminary selection based on the performances of reproductive traits, body weight, and feather colour. 


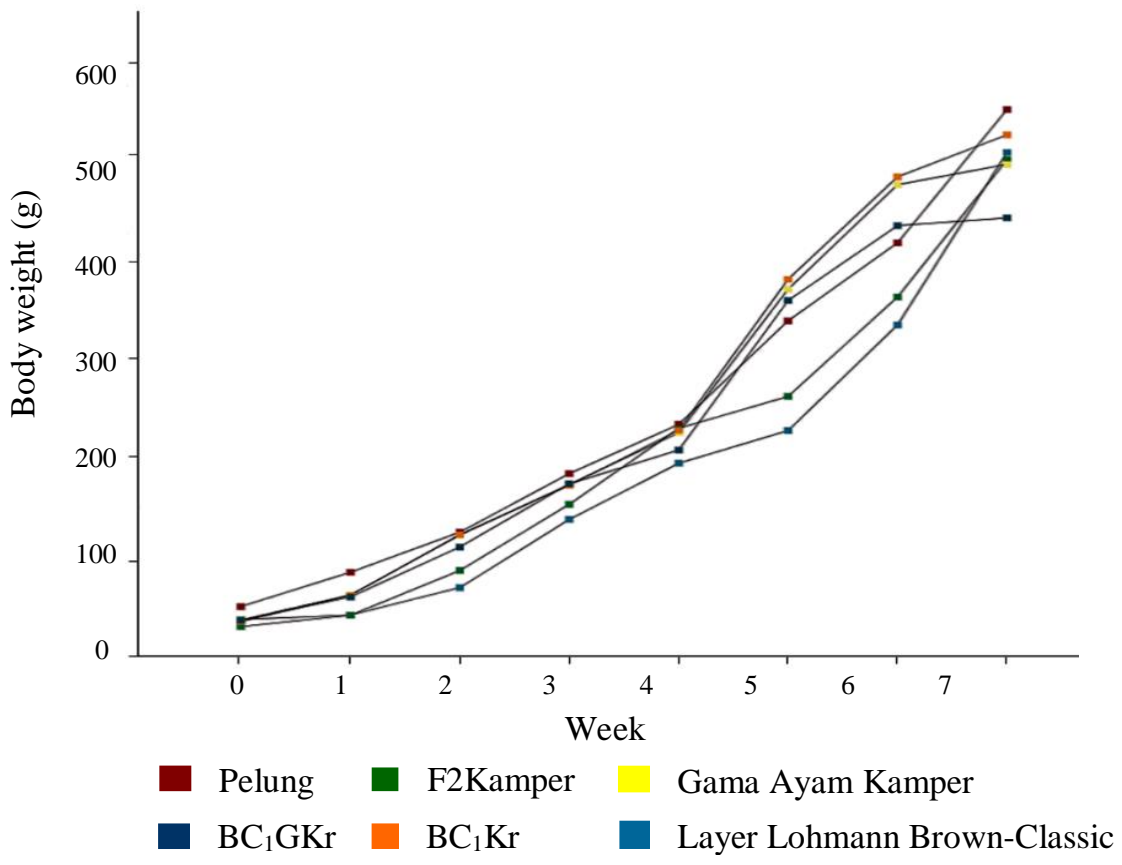

Fig. 2. Body weight of the main and the crosses progenies of Layer Lohmann Brown-Classic and Pelung chicken, during eight weeks of measurement. Colour codes= Pelung $\left(564.96^{\mathrm{a}}\right)$; Layer Lohmann Brown-Classic $\left(520.50^{\mathrm{a}}\right) ; \mathrm{F}_{2} \mathrm{Kamper}$ (513.18 $)$; Gama Ayam Kamper (508.45 $)$; $\mathrm{BC}_{1} \mathrm{Kr}\left(538.84^{\mathrm{a}}\right) ; \mathrm{BC}_{1} \mathrm{GKr}\left(453.02^{\mathrm{a}}\right)$.

At the hatching period, the body weight of Pelung (P), Layer Lohmann Brown-Classic (L), Gama Ayam Kamper (GAK), $F_{2}$ Kamper $\left(\mathrm{F}_{2} \mathrm{Kr}\right), \mathrm{BC}_{1}$ Kamper $\left(\mathrm{BC}_{1} \mathrm{Kr}\right)$ and $\mathrm{BC}_{1}$ Golden Kamper $\left(\mathrm{BC}_{1} \mathrm{GKr}\right)$, were $51.55 \mathrm{~g}, 38.11 \mathrm{~g}$, $37.75 \mathrm{~g}, 30.86 \mathrm{~g}, 36.04 \mathrm{~g}$ and $37.36 \mathrm{~g}$, respectively (Table 1, Fig. 2). The body weight (BWT) of parental cross (P) was the highest amongst other crosses, while $\mathrm{F}_{2} \mathrm{Kr}$ was the lowest $(\mathrm{P}<0.05)$. The body weight of parental cross $(\mathrm{L})$ was low $(\mathrm{P}<0.05)$ compared to that of (P).

Table 1. Commercial traits performance of main and crosses progenies of Layer Lohmann Brown-Classic and Pelung, during eight weeks measurement.

\begin{tabular}{|c|c|c|c|c|c|c|c|}
\hline Traits & $\mathrm{P}$ & $\mathrm{L}$ & GAK & $\mathrm{F}_{2} \mathrm{Kr}$ & $\mathrm{BC}_{1} \mathrm{Kr}$ & $\mathrm{BC}_{1} \mathrm{GKr}$ & SEM \\
\hline $\mathrm{BWT}_{0 \mathrm{wk}}(\mathrm{g})$ & $51.55^{\mathrm{c}}$ & $38.11^{\mathrm{b}}$ & $37.75^{\mathrm{b}}$ & $30.86^{\mathrm{a}}$ & $36.04^{b}$ & $37.36^{\mathrm{b}}$ & .26 \\
\hline $\mathrm{BWT}_{1 \mathrm{wk}}(\mathrm{g})$ & $86.95^{\mathrm{c}}$ & $42.72^{\mathrm{a}}$ & $63.60^{\mathrm{b}}$ & $42.55^{\mathrm{a}}$ & $63.04^{\mathrm{b}}$ & $61.39^{\mathrm{b}}$ & .51 \\
\hline $\mathrm{BWT}_{2 \mathrm{wk}}(\mathrm{g})$ & $128.33^{c}$ & $71.10^{\mathrm{a}}$ & $125.31^{\mathrm{c}}$ & $88.73^{\mathrm{b}}$ & $125.94^{c}$ & $113.09^{c}$ & 1.23 \\
\hline $\mathrm{BWT}_{3 \mathrm{wk}}(\mathrm{g})$ & $188.84^{\mathrm{b}}$ & $141.50^{\mathrm{a}}$ & $177.78^{b}$ & $157.18^{a}$ & $176.84^{\mathrm{b}}$ & $178.29^{b}$ & 1.46 \\
\hline $\mathrm{BWT}_{4 \mathrm{wk}}(\mathrm{g})$ & $239.71^{\mathrm{b}}$ & $199.59^{a}$ & $231.08^{\mathrm{ab}}$ & $235.68^{b}$ & $233.76^{\mathrm{b}}$ & $213.25^{\mathrm{ab}}$ & 2.45 \\
\hline $\mathrm{BWT}_{5 \mathrm{wk}}(\mathrm{g})$ & $346.75^{\mathrm{b}}$ & $233.31^{\mathrm{a}}$ & $379.38^{b}$ & $268.64^{\mathrm{a}}$ & $389.66^{\mathrm{b}}$ & $367.75^{b}$ & 3.61 \\
\hline $\mathrm{BWT}_{6 \mathrm{wk}}(\mathrm{g})$ & $427.32^{\mathrm{abc}}$ & $342.50^{\mathrm{a}}$ & $487.38^{c}$ & $371.32^{\mathrm{ab}}$ & $495.48^{c}$ & $445.07^{b c}$ & 5.15 \\
\hline $\mathrm{BWT}_{7 \mathrm{wk}}(\mathrm{g})$ & $564.96^{\mathrm{a}}$ & $520.50^{\mathrm{a}}$ & $508.45^{\mathrm{a}}$ & $513.18^{\mathrm{a}}$ & $538.84^{\mathrm{a}}$ & $453.02^{\mathrm{a}}$ & 6.09 \\
\hline $\mathrm{FL}_{8 \mathrm{wk}}(\mathrm{cm})$ & $6.59^{\mathrm{a}}$ & $6.99^{\mathrm{ab}}$ & $7.54^{\mathrm{b}}$ & $9.63^{c}$ & $6.86^{\mathrm{ab}}$ & $6.50^{\mathrm{a}}$ & .057 \\
\hline $\mathrm{TL}_{8 \mathrm{wk}}(\mathrm{cm})$ & $8.72^{\mathrm{a}}$ & $8.27^{\mathrm{a}}$ & $9.69^{\mathrm{bc}}$ & $10.43^{c}$ & $9.04^{\mathrm{ab}}$ & $8.52^{\mathrm{a}}$ & .065 \\
\hline $\mathrm{CHt}_{8 \mathrm{wk}}(\mathrm{cm})$ & $29.99^{\mathrm{a}}$ & $29.32^{\mathrm{a}}$ & $30.54^{\mathrm{a}}$ & $31.46^{\mathrm{a}}$ & $28.78^{\mathrm{a}}$ & $28.80^{\mathrm{a}}$ & .30 \\
\hline $\mathrm{BHt}_{8 \mathrm{wk}}(\mathrm{cm})$ & $20.02^{\mathrm{a}}$ & $20.45^{\mathrm{a}}$ & $21.22^{\mathrm{a}}$ & $22.13^{\mathrm{a}}$ & $19.54^{\mathrm{a}}$ & $19.55^{\mathrm{a}}$ & .21 \\
\hline $\mathrm{WS}_{8 \mathrm{wk}}(\mathrm{cm})$ & $13.72^{\mathrm{d}}$ & $9.19^{\mathrm{a}}$ & $10.54^{\mathrm{bc}}$ & $11.45^{\mathrm{c}}$ & $10.17^{\mathrm{ab}}$ & $9.93^{\mathrm{ab}}$ & .09 \\
\hline $\mathrm{CC}_{8 \mathrm{wk}}(\mathrm{cm})$ & $18.91^{\mathrm{a}}$ & $19.36^{\mathrm{ab}}$ & $21.07^{\mathrm{bc}}$ & $21.96^{\mathrm{c}}$ & $19.76^{\mathrm{ab}}$ & $19.40^{\mathrm{ab}}$ & .15 \\
\hline
\end{tabular}

Notes: a-d= The means on the same row with different supercripts are significantly different $(\mathrm{P}<0.05)$. BWT, FL, TL, CHt, BHt, WS, CC are representing the body weight $(\mathrm{g})$, femur length $(\mathrm{cm})$, tibia length $(\mathrm{cm})$, chicken height $(\mathrm{cm})$, body height $(\mathrm{cm})$, wingspan $(\mathrm{cm})$, and chest circumference $(\mathrm{cm})$; Wk= week; SEM= Standard Error of the Means; $\rho^{\mathrm{L}} \mathrm{L} \times{ }^{\lambda} \mathrm{L}=$ Layer Lohmann Brown-Classic $\times$ Layer Lohmann Brown-Classic; ${ }^{\mathrm{P}} \mathrm{P} \times{ }^{\lambda} \mathrm{P}=\mathrm{Pelung} \times \mathrm{Pelung}$;

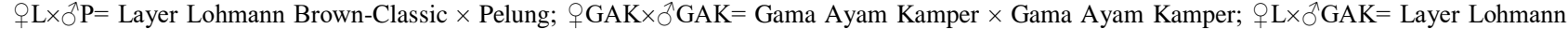
Brown-Classic $\times$ Gama Ayam Kamper; $\rho_{\mathrm{GAK} \times}{ }^{\mathrm{T}} \mathrm{F}_{2} \mathrm{Kr}=\mathrm{Gama}$ Ayam Kamper $\times \mathrm{F}_{2}$ Kamper. 
At four-weeks-old, the body weight of Pelung (P), Layer Lohmann Brown-Classic (L), Gama Ayam Kamper (GAK), $F_{2}$ Kamper $\left(\mathrm{F}_{2} \mathrm{Kr}\right), \mathrm{BC}_{1}$ Kamper $\left(\mathrm{BC}_{1} \mathrm{Kr}\right)$, and $\mathrm{BC}_{1}$ Golden Kamper $\left(\mathrm{BC}_{1} \mathrm{GKr}\right)$, were $188.84 \mathrm{~g}, 141.50 \mathrm{~g}$, $177.78 \mathrm{~g}, 157.18 \mathrm{~g}, 176.84 \mathrm{~g}$ and $178.29 \mathrm{~g}$, respectively (Table 1). The body weight (BWT) of parental cross (P) was the highest, while parental cross $(\mathrm{L})$ was the lowest $(\mathrm{P}<0.05)$. The body weight (BWT) of $\mathrm{F}_{2} \mathrm{Kr}$ was the lowest $(\mathrm{P}<0.05)$ amongst the main and the crosses progenies. At the hatching period and fourweeks-old, the body weight (BWT) measurement of the main and the crosses progenies were the lowest compared to parental cross $(\mathrm{P})$. The parental cross (L) was low compared to that of $(\mathrm{P}) \quad(\mathrm{P}<0.05)$, during hatching and four-weeks-old. Throughout the measurement, the difference in body weight growth, between the main-crosses progenies and the parental $(\mathrm{P})$, is attributable to maternal influences.

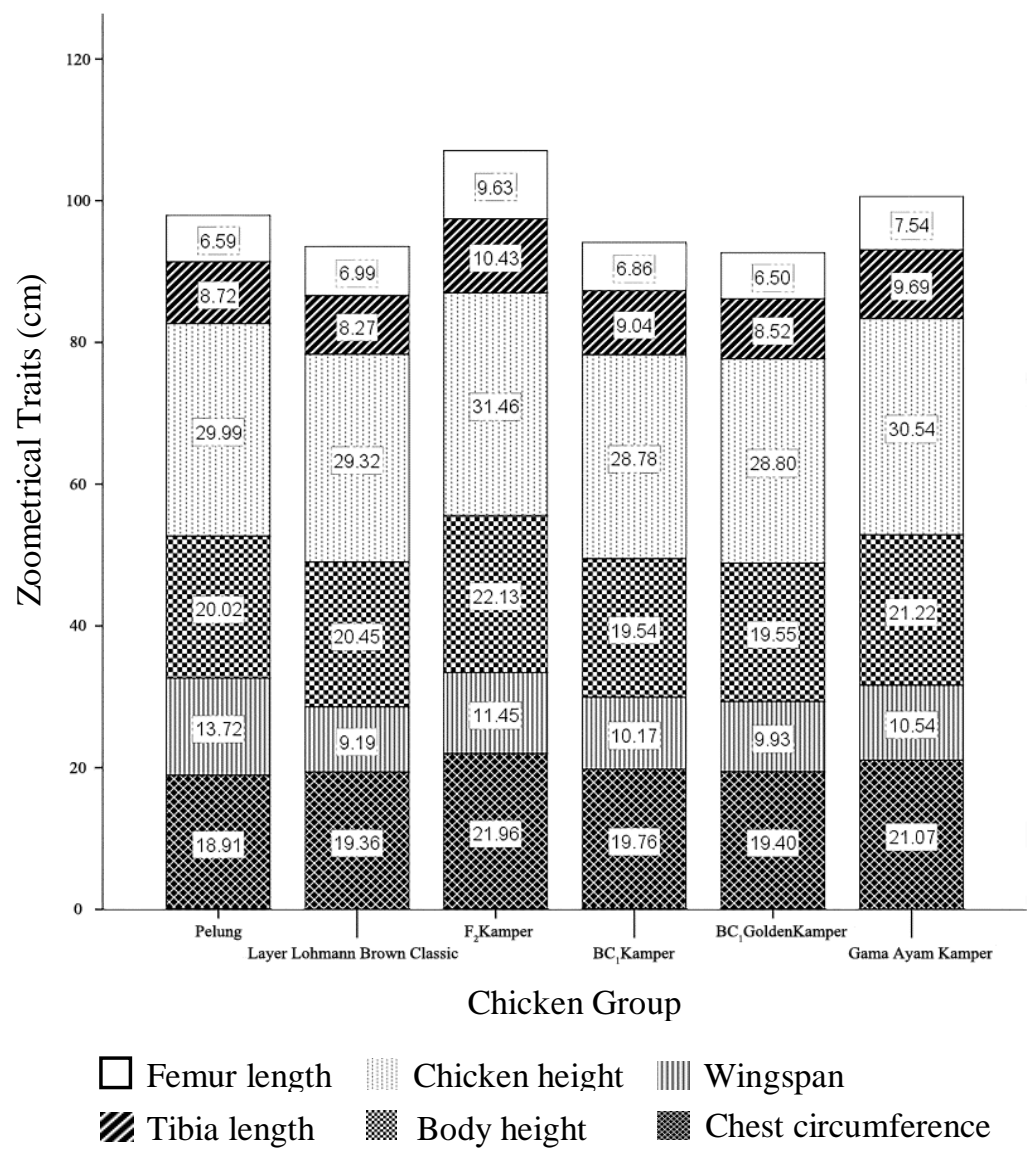

Fig. 3. Zoometrical traits measurement of main and crosses progenies of Layer Lohmann Brown-Classic and Pelung. FL, TL, CHt, BHt, WS, CC respectively femur length $(\mathrm{cm})$; tibia length $(\mathrm{cm})$; chicken height $(\mathrm{cm})$; body height $(\mathrm{cm})$; wingspan $(\mathrm{cm})$; chest circumference $(\mathrm{cm}) .+{ }_{+} \mathrm{L} \times \widehat{ }{ }^{\wedge} \mathrm{L}=$ Layer Lohmann Brown-Classic $\times$ Layer Lohmann Brown-Classic;

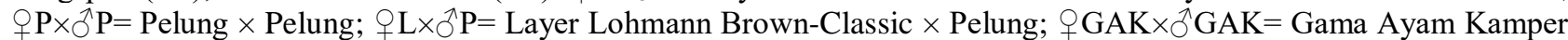
$\times$ Gama Ayam Kamper; $+\mathrm{L} \times{ }^{\lambda} \mathrm{GAK}=$ Layer Lohmann Brown-Classic $\times$ Gama Ayam Kamper; $+\mathrm{GAK} \times \overbrace{}^{\lambda} \mathrm{F} 2 \mathrm{Kr}=\mathrm{Gama}$ Ayam Kamper $\times$ F2 Kamper.

In Table 1, the estimation of other commercial traits including, the length of femur, tibia, and body, chicken height, wingspan, and chest circumference were conducted at the $8^{\text {th }}$ week. In Fig. 3, the length of femur and tibia, chicken and body height, wingspan, and chest circumference were measured as zoometrical traits, based on the guidance provided by Mahardhika \& Daryono
(2019). Femur length (FL) of $\mathrm{F}_{2} \mathrm{Kr}$ was the longest $(9.63 \mathrm{~cm}, \mathrm{P}<0.05)$, followed by GAK $(7.54 \mathrm{~cm}, \mathrm{P}<0.05)$. There was no significant $(\mathrm{P}>0.05)$ difference, between the femur length of $\mathrm{BC}_{1} \mathrm{Kr}(6.86 \mathrm{~cm})$ and parental cross (L) $(6.99$ $\mathrm{cm})$. Similar result was also observed, between the femur length of $\mathrm{BC}_{1} \mathrm{GKr}(6.50 \mathrm{~cm})$ and parental cross $(\mathrm{P})(6.59 \mathrm{~cm})$. This indicated 
maternal and paternal influences in $\mathrm{BC}_{1} \mathrm{Kr}$ and $\mathrm{BC}_{1} \mathrm{GKr}$ femur length, respectively.

Tibia length (TL) of $\mathrm{F}_{2} \mathrm{Kr}$ was the longest $(10.43 \mathrm{~cm}, \mathrm{P}<0.05)$, followed by GAK $(9.69$ $\mathrm{cm}, \mathrm{P}<0.05)$ and $\mathrm{BC} 1 \mathrm{Kr}(9.04 \mathrm{~cm}, \mathrm{P}<0.05)$. Tibia length of parental cross, $(\mathrm{P})$ and $(\mathrm{L})$ had no significant difference $(\mathrm{P}>0.05)$ with that of $\mathrm{BC}_{1} \mathrm{GKr}$. This indicated both maternal and paternal influences on $\mathrm{BC}_{1} \mathrm{GKr}$ tibia length.

$\mathrm{F}_{2} \mathrm{Kr}$ had the highest chicken height $(\mathrm{CHt})$ $(31.46 \mathrm{~cm})$ and body height $(\mathrm{BHt})(22.13 \mathrm{~cm})$, without significant difference $(\mathrm{P}>0.05)$. The wingspan (WS) of $\mathrm{BC}_{1} \mathrm{Kr}(10.17 \mathrm{~cm})$ and $\mathrm{BC}_{1} \mathrm{GKr}(9.93 \mathrm{~cm})$ were not significantly different $(\mathrm{P}>0.05)$. The wingspan of parental cross $(\mathrm{P})$ was the longest significantly $(\mathrm{P}<0.05)$, followed by $\mathrm{F}_{2} \mathrm{Kr}$ and $\mathrm{GAK}$. The parental cross (L) had the shortest wingspan of $9.19 \mathrm{~cm}$ $(\mathrm{P}<0.05)$. This indicated that the paternal influenced the main-crosses progenies.

The chest circumference (CC) of the parental cross (L), $\mathrm{BC} 1 \mathrm{Kr}$ and $\mathrm{BC} 1 \mathrm{GKr}$ had no significant differences $(\mathrm{P}>0.05)$. This indicated that the maternal influenced the $\mathrm{BC}_{1} \mathrm{Kr}$ and $\mathrm{BC}_{1} \mathrm{GKr}$ chest circumference. The chest circumference (CC) of $\mathrm{F}_{2} \mathrm{Kr}$ was the longest $(21.96 \mathrm{~cm}, \mathrm{P}<0.05)$, followed by GAK $(21.07$ $\mathrm{cm}, \mathrm{P}<0.05)$ and parental cross $(\mathrm{P})(18.91 \mathrm{~cm}$, $\mathrm{P}<0.05)$. Based on the zoometrical traits provided in Fig. 3, $F_{2}$ Kamper stood as the best cross in terms of femur and tibia length, chicken and body height, wingspan, and chest circumference.

The maternal and paternal results of the main and the acrosses commercial traits were further explained by the estimation of heterosis value. Heterosis, also termed hybridity or hybrid vigor, perhaps speeding up evolution (Bar-Zvi et al., 2017), which holds up for almost 70 years with few alterations (Lalev et al., 2014; Nwenya et al., 2017). Also, it is quantified on an individual or population basis, as the difference in the performance of the hybrid, relative to the average of the inbred parents (termed the mid parent value). For quantitative genetic analysis, the deviation of the hybrid, relative to the mid-parent, is the relevant value (Alvarez-Castro et al., 2012; Kaeppler, 2012). In a practical context, highparent heterosis, which measures the superiority of the hybrid, relative to the best parent, is the important metric (Kaeppler, 2012).

Table 2. Heterosis performance of the main and crosses progenies of Layer Lohmann Brown-Classic and Pelung.

\begin{tabular}{|c|c|c|c|c|c|c|c|}
\hline Traits & $\begin{array}{l}\text { Parental } \\
\text { Mean } \pm \text { SEM }\end{array}$ & $\begin{array}{l}\text { Crosses } \\
\text { Mean } \pm \text { SEM }\end{array}$ & $\mathrm{H} \%$ & H\%GAK & $\mathrm{H} \% \mathrm{~F}_{2} \mathrm{Kr}$ & $\mathrm{H} \% \mathrm{BC}_{1} \mathrm{Kr}$ & $\mathrm{H} \% \mathrm{BC}_{1} \mathrm{GKr}$ \\
\hline $\mathrm{BWT}_{0 \mathrm{wk}}(\mathrm{g})$ & $44.83 \pm 6.72^{\mathrm{a}}$ & $35.50 \pm 1.59^{b}$ & -20.8 & -15.79 & -18.24 & -4.98 & 8.9 \\
\hline $\mathrm{BWT}_{1 \mathrm{wk}}(\mathrm{g})$ & $64.84 \pm 22.11^{\mathrm{a}}$ & $57.65 \pm 5.05^{\mathrm{b}}$ & -11.1 & -1.91 & -33.1 & 18.58 & 15.67 \\
\hline $\mathrm{BWT}_{2 \mathrm{wk}}(\mathrm{g})$ & $99.72 \pm 28.62^{\mathrm{b}}$ & $113.27 \pm 8.70^{\mathrm{a}}$ & 13.59 & 25.67 & -29.19 & 28.24 & 5.67 \\
\hline $\mathrm{BWT}_{3 \mathrm{wk}}(\mathrm{g})$ & $165.17 \pm 23.67^{b}$ & $172.52 \pm 5.12^{\mathrm{a}}$ & 4.45 & 7.63 & -11.59 & 10.77 & 6.46 \\
\hline $\mathrm{BWT}_{4 \mathrm{wk}}(\mathrm{g})$ & $219.65 \pm 20.06^{b}$ & $228.44 \pm 5.15^{\mathrm{a}}$ & 4 & 5.2 & 1.99 & 8.56 & -8.63 \\
\hline $\mathrm{BWT}_{5 \mathrm{wk}}(\mathrm{g})$ & $290.03 \pm 56.72^{b}$ & $351.36 \pm 27.93^{\mathrm{a}}$ & 21.15 & 30.81 & -29.19 & 27.2 & 13.5 \\
\hline $\mathrm{BWT}_{6 \mathrm{wk}}(\mathrm{g})$ & $384.91 \pm 42.41^{\mathrm{b}}$ & $449.81 \pm 28.40^{\mathrm{a}}$ & 16.86 & 26.62 & -23.81 & 19.41 & 3.66 \\
\hline $\mathrm{BWT}_{7 \mathrm{wk}}(\mathrm{g})$ & $542.73 \pm 22.23^{\mathrm{a}}$ & $503.37 \pm 18.06^{\mathrm{b}}$ & -7.25 & -6.32 & 0.93 & 4.74 & -11.31 \\
\hline $\mathrm{FL}_{8 \mathrm{wk}}(\mathrm{cm})$ & $6.79 \pm 0.2^{\mathrm{b}}$ & $7.63 \pm 0.70^{\mathrm{a}}$ & 12.37 & 11.05 & 27.72 & -5.57 & -24.29 \\
\hline $\mathrm{TL}_{8 \mathrm{wk}}(\mathrm{cm})$ & $8.50 \pm 0.23^{b}$ & $9.42 \pm 0.41^{\mathrm{a}}$ & 10.82 & 14.07 & 7.64 & 0.67 & -15.31 \\
\hline $\mathrm{CHt}_{8 \mathrm{wk}}(\mathrm{cm})$ & $29.66 \pm 0.33^{b}$ & $29.90 \pm 0.67^{\mathrm{a}}$ & 0.81 & 2.98 & 3.01 & -3.84 & -7.1 \\
\hline $\mathrm{BHt}_{8 \mathrm{wk}}(\mathrm{cm})$ & $20.24 \pm 0.22^{\mathrm{b}}$ & $20.61 \pm 0.64^{\mathrm{a}}$ & 1.83 & 4.87 & 4.29 & -6.22 & -9.8 \\
\hline $\mathrm{WS}_{8 \mathrm{wk}}(\mathrm{cm})$ & $11.46 \pm 2.27^{\mathrm{a}}$ & $10.52 \pm 0.33^{b}$ & -8.20 & -7.99 & 8.63 & 3.09 & -9.69 \\
\hline $\mathrm{CC}_{8 \mathrm{wk}}(\mathrm{cm})$ & $19.14 \pm 0.23^{b}$ & $20.55 \pm 0.59^{a}$ & 7.37 & 10.11 & 4.22 & -2.25 & -9.83 \\
\hline
\end{tabular}

Notes: $\mathrm{a}, \mathrm{b}=$ Means on the same row with different supercripts are significantly different $(\mathrm{P}<0.05)$, BWT, FL, TL, CHt, BHt, WS, CC= body weight $(\mathrm{g})$, femur length $(\mathrm{cm})$, tibia length $(\mathrm{cm})$, chicken height $(\mathrm{cm})$, body height $(\mathrm{cm})$, wingspan $(\mathrm{cm})$, and chest circumference $(\mathrm{cm}) ;$ Wk= week; $\mathrm{H} \%=$ percentage heterosis; $\mathrm{H} \% \mathrm{GAK}=$ percentage heterosis from $\mathrm{P} \times \mathrm{L} ; \mathrm{H} \% \mathrm{~F}_{2} \mathrm{Kr}=$ percentage heterosis of $\mathrm{GAK} \times \mathrm{GAK} ; \mathrm{H} \% \mathrm{BC} \mathrm{Kr}_{1}=$ percentage heterosis of $\mathrm{GAK} \times \mathrm{L}$; $\mathrm{H} \% \mathrm{BC}_{1} \mathrm{GKr}=$ percentage heterosis of $\mathrm{GAK} \times \mathrm{F}_{2} \mathrm{Kr}$.

Table 2 shows the heterosis performance of the main and crosses progenies of Layer Lohmann Brown-Classic and Pelung, considering the following parameters, namely body weight (BWT), femur length (FL), tibia length (TL), chicken height (CHt), body height (BHt), wingspan (WS), and chest circumference (CC). At day old, the mean body 
weight (BWT) of parental cross (44.83 g) was higher than progenies $(35.50 \mathrm{~g})$, with a percentage heterosis $(\mathrm{H} \%)$ of -20.8 . At fourweeks-old, the mean body weight (BWT) of progenies (172.52 $\mathrm{g}$ ) was higher than parental cross $(165.17 \mathrm{~g})$, with percentage heterosis $(\mathrm{H} \%)$ of 4.45. At eight-weeks-old, the mean body weight (BWT) of progenies (503.37 g) was lower than parental cross $(542.73 \mathrm{~g})$, with percentage heterosis $(\mathrm{H} \%)$ of -7.25 . The overall performance of progenies compared with parental cross, were higher with simultaneously higher percentage heterosis $(\mathrm{H} \%)$, during the period of three to six weeks-old.

At a-day-old, based on mean body weight percentage, heterosis across progenies were 15.70 (H\%GAK), $-18.24 \quad\left(\mathrm{H} \% \mathrm{~F}_{2} \mathrm{Kr}\right), \quad-4.98$ $\left(\mathrm{H} \% \mathrm{BC}_{1} \mathrm{Kr}\right)$, and $8.9\left(\mathrm{H} \% \mathrm{BC}_{1} \mathrm{GKr}\right)$. At fourweeks-old, based on mean body weight percentage, heterosis across progenies were 7.63 (H\%GAK), $-11.59 \quad\left(\mathrm{H} \% \mathrm{~F}_{2} \mathrm{Kr}\right), \quad 10.77$ $\left(\mathrm{H} \% \mathrm{BC}_{1} \mathrm{Kr}\right)$, and $6.46\left(\mathrm{H} \% \mathrm{BC}_{1} \mathrm{GKr}\right)$. At eightweeks-old, based on the mean body weight percentage, heterosis across progenies were 6.32 (H\%GAK), $0.93 \quad\left(\mathrm{H} \% \mathrm{~F}_{2} \mathrm{Kr}\right), \quad 4.74$ $\left(\mathrm{H} \% \mathrm{BC}_{1} \mathrm{Kr}\right)$, and $-11.31 \quad\left(\mathrm{H} \% \mathrm{BC}_{1} \mathrm{GKr}\right)$. Percentage heterosis of progenies were ranked collectively, from the most positive to the negative as $\mathrm{H} \% \mathrm{BC}_{1} \mathrm{Kr}, \mathrm{H} \% \mathrm{BC}_{1} \mathrm{GKr}, \mathrm{H} \% \mathrm{GAK}$, and $\mathrm{H} \% \mathrm{~F}_{2} \mathrm{Kr}$. In pre-conclusion, progenies of backcross between GAK and Layer Lohmann Brown-Classic, performed more than others, during eight weeks of semi-intensive rearing system.

The zoometrical traits percentage of parental cross heterosis, collectively was lower than the progenies, except for WS (H\%: -8.20). Across other traits including FL (H\%: 12.37), TL (H\%: 10.82), CHt (H\%: 0.81), BHt (H\%: 1.83), and $\mathrm{CC}(\mathrm{H} \%$ : 7.37), their progenies showed improvement in terms of performance. Based on positive heterosis value, progenies were ranked from the most positive to the negative, $\mathrm{H} \% \mathrm{~F} 2 \mathrm{Kr}, \mathrm{H} \% \mathrm{GAK}, \mathrm{H} \% \mathrm{BC}_{1} \mathrm{Kr}$, and $\mathrm{H} \% \mathrm{BC} 1 \mathrm{GKr}$. In pre-conclusion, the progenies of inter-cross (inbreeding) between GAK, performed more than other progenies, during eight weeks of semi-intensive rearing system.

The interpretation of heterosis value is deduced by estimating the inbreeding depression and rate. The converse hybrid vigor is the inbreeding depression caused by increased homozygosity of individuals, which reduces survival, fitness, and fertility of offspring (Sanghera et al., 2011; Larièpe et al., 2012; Pekkala et al., 2014). The estimation of inbreeding depression, provide a valuable insight into what measure and approach is taken to compensate its effects on selective breeding program. The inbreeding aspects have been investigated in Indonesia, mostly in agriculture (Ali et al., 2019), poultry and fishery sector (Binur \& Pancoro, 2017), and also in black winged starling (Sturnus melanopterus) conservation (Maulana et al., 2015).

Based on the percentage heterosis value of $\mathrm{F}_{2} \mathrm{Kr}$ and $\mathrm{BC}_{1} \mathrm{Kr}$, with a different performance, $\mathrm{F}_{2} \mathrm{Kr}$ showed superior performance in zoometrical traits, while $\mathrm{BC}_{1} \mathrm{Kr}$ indicated superior performance in the body weight. Across all commercial traits, the progenies were ranked into most positive to negative, $\mathrm{H} \% \mathrm{BC}_{1} \mathrm{Kr}, \mathrm{H} \% \mathrm{~F}_{2} \mathrm{Kr}, \mathrm{H} \% \mathrm{GAK}$, and $\mathrm{H} \% \mathrm{BC}_{1} \mathrm{GKr}$. The progenies of backcross between $\mathrm{GAK}$ and $\mathrm{F}_{2} \mathrm{Kr}$, showed the most negative performance in commercial traits. Table 3 describes the inbreeding depression $(\mathrm{Fx})$ and inbreeding rate $(\mathrm{F})$ of each chicken group. Based on these two factors, $\mathrm{BC}_{1} \mathrm{GKr}$ was the highest, Fx: 0.375 and F: 0.3125 . Perdamaian et al. (2017) stated that declining performance was influenced by inbreeding depression. Declining performance in the body weight observed in $\mathrm{BC}_{3}$ Kambro Gama Ayam was influenced by inbreeding (Perdamaian et al., 2017). In pre-conclusion, an outbreeding should be introduced to tackle the unproductive alleles in the gene pool. Nietlisbach et al. (2017) stated that inbreeding depression is caused by probability increase of identical-bydescent (IBD). The increase homozygosity, associated with fitness decline, was caused by unproportional expression of several recessive or homozygot alleles (Hedrick \& GarciaDorado, 2016; Harrisson et al., 2019). These are inherited and expressed inferior phenotype character than heterozygote alleles (Nietlisbach et al., 2017). The use of genomic selection, using gene marker and microsatellite, suppress the rate of inbreeding depression and rate 
(Nietlisbach et al., 2017). Wolc et al. (2015) reported lower inbreeding depression and rate in 16 layer lines, using genomic rather than conventional selection method.

Table 3. Inbreeding coefficient and inbreeding rate of each chicken group.

\begin{tabular}{lll}
\hline Chicken Group & Fx & $\mathrm{F}$ \\
\hline Gama Ayam & 0 & 0.0834 \\
Kamper & & \\
$\mathrm{F}_{2}$ Kamper & 0.25 & 0.375 \\
$\mathrm{BC}_{1}$ Kamper & 0.25 & 0.25 \\
$\mathrm{BC}_{1}$ Golden & 0.375 & 0.3125 \\
Kamper & & \\
Notes: Fx= inbreeding coefficient; F= inbreeding rate
\end{tabular}

Based on phenotypic traits of feather and shank colour between parental cross, the main and crosses progenies, were the defining pattern of inheritance and expression. In the main progenies (GAK), feather colour was classified into 5 groups, while that of shank was categorized into 3. Feather and shank colour, resulting from the progeny crosses of $\mathrm{F}_{2} \mathrm{Kr}$, $\mathrm{BC}_{1} \mathrm{Kr}$, and $\mathrm{BC}_{1} \mathrm{GKr}$, were differentiated into the following groups $5 \& 3,6 \& 3$, and $7 \& 3$, respectively. The short and long-term selection were considered in this study. Quantitative traits and its association with chromosomal regions have been studied using quantitative trait loci (QTL). Advanced breeding program and breeder utilizes this method to identify genes or mutations in chicken. The methods for QTL mapping used in the chicken to identify chromosomal regions (Wang et al., 2012), contributed to variation in traits, relating to growth (Goto et al., 2019), disease resistance (Luo et al., 2013), egg production (Lien et al., 2020), behavior (Johnsson et al., 2018), and metabolic parameters (Mignon-Grasteau et al., 2016).

Reproductive Traits and Egg Nutritional Content. Table 3 describes reproductive traits of parental cross, main and crosses progenies. EP 16week $_{\text {and Hen Day }}$ Production (HDP) of progenies were ranked from the highest to the lowest as $\mathrm{F}_{2} \mathrm{Kr}, \mathrm{BC}_{1} \mathrm{GKr}$, $\mathrm{GAK}$, and $\mathrm{BC}_{1} \mathrm{Kr}$. Maternal influences were attributed to the EP + HDP of progenies, compared to parental cross $(\mathrm{P})$ with the lowest value of 27.2 (0.6). EW progenies also showed influences from maternal cross (L), with the backcross $\mathrm{GAK} \times \mathrm{L}$ and $\mathrm{BC}_{1} \mathrm{Kr}$ ranked as the heaviest. EW progenies showed clear improvement in performance compare to $\mathrm{P}$ with the lightest weight of $48.15 \mathrm{~g}$.

Heritability estimates are usually categorized into three classes viz: low (0-0.19), moderate (0.2- 0.39), and high (0.4 and above), with their values in all classes ranging from $0-1$ or 0 - 100\% (Alwell et al., 2018). It was estimated based on ES and EW, from eggs of progenies and parental. Heritability of $\mathrm{BC}_{1} \mathrm{Kr}$ $\left(\mathrm{h}^{2}: 0.2-0.244\right.$, low), was ranked as moderate amongst the progenies and parental cross. Therefore, in terms of heritability, $\mathrm{BC}_{1} \mathrm{Kr}$ performed superior to other crosses, although requires significant improvement. Progenies and parental crosses showed various range in heritability from low-moderate to low-high. This produced significant impact in terms of egg weight and shape stability, while similarity and consistency are keys in commercialization. To explain this phenomenon, it is important not to solely depend on genetic factors. Other influential factors also intervene, for example age of laying, feed, and environment. Alwell et al. (2018) reported that since egg weight yielded high estimates at various age groups, the low and moderate heritability, recorded for egg shell weight, imply that collection of additional records and improvement of nongenetic factors influencing the trait, are capable of developing the accuracy of characterizing the inherent ability of the birds. 


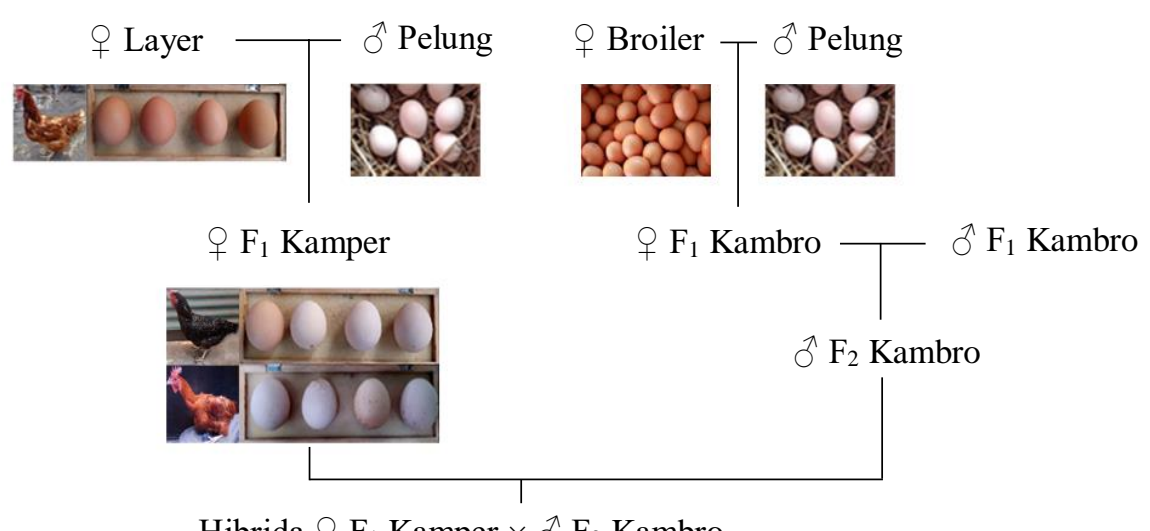

Hibrida $q \mathrm{~F}_{1}$ Kamper $\times \widehat{\jmath} \mathrm{F}_{2}$ Kambro

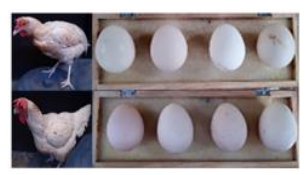

Fig. 4. Egg color and egg appearance comparison with other chicken breed.

Fig. 4 describes the egg colour and appearance comparison of Kamper chicken, in line with other breeds. The egg colour of progenies were strongly influenced by paternal alleles, with $\mathrm{GAK}$ and $\mathrm{BC}_{1} \mathrm{Kr}$, showing similarity with Layer Lohmann Brown-Classic, while $\mathrm{GAK}, \mathrm{F}_{2} \mathrm{Kr}$, and $\mathrm{BC}_{1} \mathrm{GKr}$ indicated similarity with Pelung (Table 4). Protoporphyrin IX, biliverdin and its zinc chelates play a role in brown eggshell coloration (Samiullah et al., 2015; Poláček et al., 2017; Bi et al., 2018).

Table 4. Reproductive traits performance of main and crosses progenies of Layer Lohmann Brown-Classic and Pelung during 16 weeks observation.

\begin{tabular}{lllllll}
\hline Traits & $\mathrm{GAK}$ & $\mathrm{F}_{2} \mathrm{Kr}$ & $\mathrm{BC}_{1} \mathrm{Kr}$ & $\mathrm{BC}_{1} \mathrm{GKr}$ & $\mathrm{P}$ & $\mathrm{L}$ \\
\hline $\mathrm{EP}_{16 \mathrm{wk}}(\mathrm{HDP})$ & $55.58(0.67)$ & $58.50(0.71)$ & $39.11(0.6-0.67)$ & $57.04(0.69)$ & $27.2(0.6)$ & $71.89(1.29)$ \\
$\mathrm{ES}(\mathrm{cm})$ & 0.77 & 0.74 & 0.77 & 0.76 & 0.70 & 0.79 \\
$\mathrm{~h}^{2}(\%)$ & $0.2-0.4$ & $0.15-1.0$ & $0.2-0.244$ & $0.18-0.75$ & $0.12-0.47$ & $0.05-0.244$ \\
$\mathrm{EC}$ & Pale White & Pale White & Pale Brown & Pale White & White & Brown \\
$\mathrm{h}^{2}$ group & low-high & low-high & moderate & low-high & low-high & low-moderate \\
$\mathrm{EW}(\mathrm{g})$ & 50.33 & 53.95 & 58.8 & 57.95 & 48.15 & 59.4 \\
\hline
\end{tabular}

Notes: $E P=$ Egg productivity; $E S=$ Egg shape; $\mathrm{h}^{2}=$ Heritability; $\mathrm{EC}=$ Eggshell color; $\mathrm{EW}=$ Egg weight; $\mathrm{Wk}=\mathrm{Week}$

Sarica \& Erensayin (2009) underlined that eggs were classified with respect to shape index (SI), namely sharp (SI $<72)$, standard (normal) $(\mathrm{SI}=72-76)$, and round (SI>76). In Table 4, both $\mathrm{GAK}$ and $\mathrm{BC}_{1} \mathrm{Kr}$ backcross progenies of GAK $\times$ L, showed egg shape (round) similarity with Layer Lohmann Brown-Classic. Both $\mathrm{F}_{2} \mathrm{Kr}$ and $\mathrm{BC}_{1} \mathrm{GKr}$ are standard egg which were influenced by both parental (P) and (L). Setiawati et al. (2016) found that, genetic factor solely determines the egg shape, and there is no correlation between the management system and temperature of egg shape. In comparison with other laying-type breed, for example Layer ISA Brown and ISA White, Kamper showed a significant similarity. Kabir et al. (2012) reported that egg shape of Layer ISA Brown and ISA White respectively were $79.90 \mathrm{~cm}$ (round egg) and $72.08 \mathrm{~cm}$ (standard egg). Egg proximate analysis of $\mathrm{GAK}, \mathrm{F}_{2} \mathrm{Kr}$, and $\mathrm{BC}_{1}$ showed the protein content of $10.57 \%, 11.63 \%$, and $10.72 \%$, respectively. And also, the carbohydrate and fatty acid content of $10.38 \%$ \& $3.43 \%(\mathrm{GAK}), 9.06 \% \& 3.27 \%\left(\mathrm{~F}_{2} \mathrm{Kr}\right)$, and $9.28 \% \& 3.09 \%\left(\mathrm{BC}_{1}\right)$.

\section{CONCLUSION}

Based on commercial traits, the phenotypic and reproductive types of progenies in Kamper chicken, have significant improvements 
compared to the parental crossing of Pelung breed and Layer Lohmann Brown-Classic. The quantitative genetic method was used in describing and underlying some phenomenon in the selective breeding program. Although, this technique was utilized in the basic breeding program with significant precision and rapidness, it was also a preliminary study in the advance breeding program. Therefore, the addition of quantitative trait loci, provides a more thorough genetic examination, and play a role in selective breeding program.

\section{ACKNOWLEDGEMENTS}

The authors thank Gama Ayam Research Team, Laboratory of Genetics and Breeding, Faculty of Biology, UGM, and Pusat Inovasi Agro Teknologi UGM for the continuous support of this study. This research was supported by Stranas Research Grant (Penelitian Strategis Nasional Institusi No. 1734/ UN1/DITLIT/DIT-LIT/2018) of Kementerian Riset, Teknologi dan Pendidikan Tinggi Republik Indonesia in 2018. In 2019 this research continues with funding support of Applied Research Grant (Penelitian Terapan/PT No. 2830/UN1.DITLIT/DITLIT/LT/2019) of Kementerian Riset dan Teknologi/Badan Riset dan Inovasi Nasional Republik Indonesia.

\section{REFERENCES}

Ali M, Kuswanto K, Kustanto H. 2019. Phenomenon of inbreeding depression on maize in perspective of the Quran. Agrivita, Journal of Agricultural Science. vol 41(2): 385-393. doi: http://doi.org/10.17503/agrivita.v41i2.2022.

Alvarez-Castro JM, Le Rouzic A, Andersson L, Siegel PB, Carlborg Ö. 2012. Modelling of genetic interactions improves prediction of hybrid patternsa case study in domestic fowl. Genetics Research. vol 94(5): 255-266. doi: https://doi.org/10.1017/S001667231200047X.

Alwell JJS, Abdur-Rahman A, Chukwujindu NS. 2018. Heritability estimates of egg weight and eggshell weight in Ikenne, Nigeria. International Journal of Scientific World. vol 6(1): 38-42. https://doi.org/10.14419/ijsw.v6i1.8677.

Anderson KE, Tharrington JB, Curtis PA, Jones FT. 2004. Shell characteristics of eggs from historic strains of single comb white leghorn chickens and the relationship of egg shape to shell strength. International Journal of Poultry Science. vol 3(1): 17-19.
Bar-Zvi D, Lupo O, Levy AA, Barkai N. 2017. Hybrid vigor: The best of both parents, or a genomic clash? Current Opinion in Systems Biology. vol 6: 22-27. doi: https://doi.org/10.1016/j.coisb.2017.08.004.

Bi H, Liu Z, Sun C, Li G, Wu G, Shi F, Liu A, Yang N. 2018. Brown eggshell fading with layer ageing: dynamic change in the content of protoporphyrin IX. Poultry Science. vol 97(6): 1948-1953. doi: https://doi.org/10.3382/ps/pey044.

Binur R, Pancoro A. 2017. Inbreeding depression level of post-larvae freshwater prawn (Macrobrachium rosenbergii) from several hatcheries in Java, Indonesia. Biodiversitas. vol 18(1): 609-618. doi: https://doi.org/10.13057/biodiv/d180159.

Cheng HW. 2010. Breeding of tomorrow's chickens to improve well-being. Poultry Science. vol 89: 805813. doi: https://doi.org/10.3382/ps.2009-00361.

Diambra-Odi H. 2014. Tropical layer chicken management guide: A sustainable approach. Bloomington: Xlibris Publishing. pp 1-104.

Duman M, Şekeroğlu A, Yıldırım A, Eleroğlu H, Camcı Ö. 2016. Relation between egg shape index and egg quality characteristics. European Poultry Science. vol 80: 1-9. doi: https://doi.org/10.1399/eps.2016.117.

Goto T, Ishikawa A, Nishibori M, Tsudzuki M. 2019. A longitudinal quantitative trait locus mapping of chicken growth traits. Molecular Genetics and Genomics. vol 294(1): 243-252. doi: https://doi.org/10.1007/s00438-018-1501-y.

Harrisson KA, Magrath MJ, Yen JD, Pavlova A, Murray N, Quin B, Menkhorst P, Miller KA, Cartwright K, Sunnucks P. 2019. Lifetime fitness costs of inbreeding and being inbred in a critically endangered bird. Current Biology. vol 29(16): 2711-2717.

doi: https://doi.org/10.1016/j.cub.2019.06.064.

Hedrick PW, Garcia-Dorado A. 2016. Understanding inbreeding depression, purging, and genetic rescue. Trends in Ecology \& Evolution. vol 31(12): 940952.

doi: https://doi.org/10.1016/j.tree.2016.09.005.

Henuk YL, Bakti D. 2018. Benefits of Promoting Native Chickens for Sustainable Rural Poultry Development in Indonesia. Talenta Conference Series: Agricultural and Natural Resources (ANR). vol 1(1): 69-76. doi: https://doi.org/10.32734/anr.v1i1.98.

Johnsson M, Henriksen R, Fogelholm J, Höglund A, Jensen P, Wright D. 2018. Genetics and genomics of social behavior in a chicken model. Genetics. vol 209(1): 209-221. doi: https://doi.org/10.1534/genetics.118.300810.

Kabir MA, Islam MS, Datta RK. 2012. Egg morphometric analyses in chickens and some selected birds. University Journal of Zoology, Rajshahi University. vol 31: 85-87.

Katano T, Shimogiri T, Kawabe K, Okamoto S. 2011. Genetic diversity and population structure of Indonesian native chickens based on single 
nucleotide polymorphism markers. Poultry Science. vol 90(11): 2471-2478. doi: https://doi.org/10.3382/ps.2011-01450.

Kaeppler S. 2012. Heterosis: many genes, many mechanisms - end the search for an undiscovered unifying theory. International Scholarly Research Notices. $\quad$ vol 2012: 1-13. doi: https://doi.org/10.5402/2012/682824.

Lalev M, Mincheva N, Oblakova M, Hristakieva P, Ivanova I. 2014. Estimation of heterosis, direct and maternal additive effects from crossbreeding experiment involving two White Plymouth Rock lines of chickens. Biotechnology in Animal Husbandry. vol 30(1): 103-114. doi: https://doi.org/10.2298/BAH1401103L.

Lien CY, Tixier-Boichard M, Wu SW, Chen CF. 2020. Identification of QTL and loci for egg production traits to tropical climate conditions in chickens. Livestock Science, vol 234: 1-9. doi: https://doi.org/10.1016/j.livsci.2020.103980.

Luo C, Qu H, Ma J, Wang J, Li C, Yang C, Hu X, Li N, Shu D. 2013. Genome-wide association study of antibody response to Newcastle disease virus in chicken. BMC Genetics. vol 14(1): 1-9. doi: https://doi.org/10.1186/1471-2156-14-42.

Mahardhika IWS, Daryono BS. 2019. Phenotypic performance of Kambro crossbreeds of female Broiler Cobb 500 and male Pelung Blirik Hitam. Buletin Veteriner Udayana. vol 11(2): 188-202. doi: https://doi.org/10.24843/bulvet.2019.v11.i02.p12.

Manjula P, Park HB, Seo D, Choi N, Jin S, Ahn SJ, Heo KN, Kang BS, Lee JH. 2018. Estimation of heritability and genetic correlation of body weight gain and growth curve parameters in Korean native chicken. Asian-Australasian Journal of Animal Sciences. vol 31(1): 26-31. doi: https://doi.org/10.5713/ajas.17.0179.

Maulana B, Masy'ud B, Mardiastuti A. 2015. Identifikasi inbreeding pada jalak putih (Sturnus melanopterus Daudin 1800) di pusat penyelamatan Satwa Cikananga, Jawa Barat. Media Konservasi. vol 20(1): 21-26. doi: https://doi.org/10.29244/medkon.20.1.\%25p.

Mignon-Grasteau S, Chantry-Darmon C, Boscher MY, Sellier N, Chabault-Dhuit M, Le Bihan-Duval E, Narcy A. 2016. Genetic determinism of bone and mineral metabolism in meat-type chickens: A QTL mapping study. Bone Reports. vol 5: 43-50. doi: https://doi.org/10.1016/j.bonr.2016.02.004.

Mottet A, Tempio G. 2017. Global poultry production: current state and future outlook and challenges. World's Poultry Science Journal. vol 73(2): 245256.

doi: https://doi.org/10.1017/S0043933917000071.

Nietlisbach P, Keller LF, Camenish G, Guillaume F, Arcesee P, Reid JM, Postma E. 2017. Pedigreebased inbreeding coefficient explains more variation in fitness than heterozygosity at 160 microsatellites in a wild bird population.
Proceedings of the Royal Society B. vol 284(1850): 2016-2763.

doi: https://doi.org/10.1098/rspb.2016.2763.

Niknafs SH, Abdi H, Fatemi SA, Zandi MB, Baneh H. 2013. Genetic trend and inbreeding coefficients effects for growth and reproductive traits in Mazandaran indigenous chicken. Journal of Biology. vol 3(1): 25-31.

Nwenya JMI, Nwakpu EP, Nwose RN, Ogbuagu KP. 2017. Performance and heterosis of indigenous chicken crossbreed (Naked Neck x Frizzled Feather) in the humid tropics. Journal of Poultry Research. vol 14(2): 7-11.

Pekkala N, Knott KE, Kotiaho JS, Nissinen K, Puurtinen M. 2014. The effect of inbreeding rate on fitness, inbreeding depression and heterosis over a range of inbreeding coefficients. Evolutionary Applications. vol 7(9): 1107-1119. doi: https://doi.org/10.1111/eva.12145.

Perdamaian ABI, Trijoko T, Daryono BS. 2017. Growth and plumage color uniformity of back cross (BC2) chicken resulted from genetics selection of pelung chicken and broiler crossed. Jurnal Veteriner. vol 18(4): 557-564. doi: https://doi.org/10.19087/jveteriner.2017.18.4.557.

Poláček M, Griggio M, Mikšík I, Bartíková M, Eckenfellner M, Hoi H. 2017. Eggshell coloration and its importance in postmating sexual selection. Ecology and Evolution. vol 7(3): 941-949. doi: https://doi.org/10.1002/ece3.2664.

Reddy PM, Reddy VR, Reddy CV, Rao PSP. 1979. Egg weight, shape index and hatachability in Khaki Campbell duck eggs. Indian Journal of Poultry Science. vol 14(1): 26-31.

Risdianto D, Suthama N, Suprijatna E, Sunarso S. 2019. Inclusion effect of ginger and turmeric mixture combined with Lactobacillus spp. isolated from rumen fluid of cattle on health status and growth of broiler. Journal of the Indonesian Tropical Animal Agriculture. vol 44(4): 423-433. doi: https://doi.org/10.14710/jitaa.44.4.423-433.

Samaraweera AM, Silva P, Abeykone NDF, Ibrahim MNM, Okeyo AM, Han JL. 2014. Population genetic structure of Sri Lankan backyard chicken flocks: Implication for conservation and genetic improvement programs. Proceeding 10th World Congress of Genetics Applied to Livestock Production. August 17-22, 2014. Vancouver: American Society of Animal Science. p 448.

Samiullah S, Roberts JR, Chousalkar K. 2015. Eggshell color in brown-egg laying hens-a review. Poultry Science. vol 94(10): 2566-2575. doi: https://doi.org/10.3382/ps/pev202.

Sarica M, Erensayin C. 2009. Tavukçuluk ürünleri. Tavukçuluk Bilimi, Yetiştirme, Besleme ve Hastalıklar, Ed. M. Türkoğlu, M. Sarıca. Ankara: Bey Ofset Matbaacılık. p 89-139.

Sawitri R, Takandjandji M. 2012. Inbreeding pada Populasi Banteng (Bos javanicus d'Alton 1832) di Kebun Binatang Surabaya. Buletin Plasma Nutfah. 
vol 18(2): 84-94. doi: http://dx.doi.org/10.21082/blpn.v18n2.2012.p8494.

Setiawati T, Afnan R, Ulupi N. 2016. Performa produksi dan kualitas telur ayam petelur pada sistem litter dan cage dengan suhu kandang berbeda. Jurnal Ilmu Produksi dan Teknologi Hasil Peternakan. vol 4(1): 197-203.

Stamps J, Groothuis TG. 2010. The development of animal personality: relevance, concepts and perspectives. Biological Reviews. vol 85(2): 301325. doi: https://doi.org/10.1111/j.1469185X.2009.00103.x.

Tallentire CW, Leinonen I, Kyriazakis I. 2018. Artificial selection for improved energy efficiency is reaching its limits in broiler chickens. Scientific Reports. vol 8(1): 1-10. doi: https://doi.org/10.1038/s41598018-23133-8.

Telalbašić R, Baban M, Rahmanović A. 2007. Inbreeding. Biotechnology in Animal Husbandry. vol 23(5-6): 113-130. https://doi.org/10.2298/BAH0702113T.
Ummah IM, Mahardhika IWS, Daryono BS. 2019. Morphological traits, productive performance and genotyping fat deposition PPAR gene in Gama Ayam crossbreeds of female F1 Kamper and male BC1 Kambro. Biogenesis: Jurnal Ilmiah Biologi. vol 7(2): 106-115. doi: https://doi.org/10.24252/bio.v7i2.9993.

Wang SZ, Hu XX, Wang ZP, Li XC, Wang QG, Wang YX, Tang ZQ, Li H. 2012. Quantitative trait loci associated with body weight and abdominal fat traits on chicken chromosomes 3, 5 and 7. Genetics and Molecular Research. vol 11(2): 956-965. doi: http://dx.doi.org/10.4238/2012.April.19.1.

Wolc A, Zhao HH, Arango J, Settar P, Fulton JE, O’Sullivan NP, Preisinger R, Stricker C, Habier D, Fernando RL, Garrick DJ, Lamont SJ, Dekker JCM. 2015. Response and inbreeding from a genomic selection experiment in layer chickens. Genomic Selection Evolution. vol 47: 1-12. doi: https://doi.org/10.1186/s12711-015-0133-5. 